DOI: https://doi.org/10.21564/2707-7039.2.242858

УAK $340.13 ; 340.14$

\title{
Віктор Смородинський*
}

\section{ПРАВОВА ВИЗНАЧЕНІСТЬ**}

учасний концепт правової визначеності як загамьного принципу права та вимоги верховенства права увібрав у себе усі важливі досягнення історії правової думки та практики їі реалізації правовими системами - як національними, так і міжнародними. Водночас він постійно розвивається й УАосконалюється. Його Ажерелами $є$ передусім правова Аоктрина й судова практика. Будь-яке грунтовне Аослідження принципів права, верховенства права не оминає й питань правової визначеності. 3 найцікавіших вітчизняних наукових розвідок варто віАзначити праці О. Беляневич, $\Lambda$. Богачової, С. Головатого, Ю. Матвєєвої, С. Погребняка. Автор цієї статті піА час АосліАжень загацьнотеоретичних пробцем судової влаАи, верховенства права, ефективності правового регулювання також неодноразово висвітлював проблеми правової визначеності, що мають місце як у правовому регулюванні, так і в судовій практиці. ${ }^{1}$

Правова визначеність (legal certainty, у різних Ажерелах переклалається ще як «юриАична визначеність» та «правопевність») є загальним принципом права та вимогою верховенства права, що передбачає Аегкість і доступність з'ясування змісту права та юридично забезпечену можливість скористатися цим правом. ВіАповіАно Ао цієї вимоги: усі правові акти мають публікуватися та виклаАатися зрозумілою мовою; зворотну дію нормативно-правових актів має бути заборонено (крім прямо визначених законом винятків, запроваджених з метою покращення становища приватних осіб); судова практика національних судів має бути послідовною; національне законодавство має бути придатним Аля застосування із забезпеченням його виконання; оцінювання законодавства має зАійснюватися на регумярній основі. ${ }^{2}$

\footnotetext{
* Віктор Семенович Смородинський, кандидат юридичних наук, доцент кафеАри теорії і філософії права, Національний юридичний університет імені Ярослава Мудрого.

Viktor Smorodynskyi, Candidate of Legal Sciences, Associate Professor at the Department of Theory and Philosophy of Law, Yaroslav Mudryi National Law University.

e-mail: vsmorod@gmail.com

** Стаття є розширеною версією мекції з навчальної Аисципліни «Верховенство права», що викладається автором студентам 4 курсу факультету аАвокатури Національного юриАичного університету імені Ярослава Муарого. - Прим. редакції.

${ }^{1}$ Віктор Смородинський, “Судова влада в Україні (загальнотеоретичні проблеми)” (Аис. ... канА. юриА. наук, Харків, 2001).

${ }^{2}$ Олександр Петришин та ін. Загальна теорія права. ПіАручник (Харків: Право, 2020), 504.
} 
Правова визначеність $є$ не мише одним із загальних принципів права та однією з вимог його «верховенства» (за класифікацією С. Погребняка, оАним із принципів, що забезпечують Аію верховенства права ${ }^{3}$ ), а й загалом засадничою властивістю й умовою значущості права та його інструментацьної цінності як системного засобу регулювання віАносин між мюАьми та їхніми групами (колективами) в суспільстві. Підтвердженням цієї позиції є, зокрема, аналіз наукових розвіАок віАомих захіАних філософів і теоретиків права, які ще задовго до появи цього спеціального терміна в юридичній науці та судовій практиці розгляАали правову визначеність і як важливу (якщо не найважливішу) вимогу верховенства права наА Аержавним свавілмям, і як вирішальну умову моральності та ефективності права, нормотворчої та правозастосовної аіяльності.

Так, австро-англійський помітичний філософ та економіст, мауреат Нобелівської премії Фрідріх Авлуст фон Гаєк запропонував таке визначення принципу верховенства права: « ... ие означає, щзо уряд має виконувати правила, встановлені й проголочені заздалегід b, - правила, що дають змогу з певністю передбачати, як влада використовуватиме свої повноваження здійснення примусу за певних обставин і планувати власні справи на nідставі цъвого знання >. ОАнією з трьох ознак такого закону є його доступність та очевидність - результат його застосування й тлумачення має бути переАбачуваним, очевидним. За висловом Гаєка, «важко перебільшити ту вагу, яку має очевидність закону Аля поступального й ефективного руху вільного суспільства». Як зазначає мислитель, мише за умови віАповіАності законів цим ознакам «можна говорити, щзо правлять закони, а не ююди». ${ }^{4}$

3 восьми вимог до нормотворчості та правозастосування, що буми сформумьовані американським філософом права, професором ГарварАської школи права

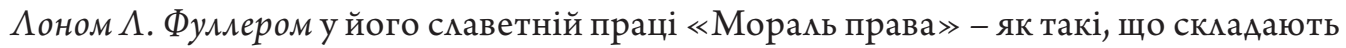
так звану «внутрішню моральність права», сім $€$ фактично вимогами саме правової визначеності: закони мають бути оприлюАнені, щоб громаАяни знали норми, яких вони повинні дотримуватися; ухвахення й застосування законів, що мають зворотну Аію, сліА звести Ао мінімуму; закони мають бути зрозумілими; закони не повинні бути суперечливими; закони не повинні вимагати Аій, що виходять за межі спроможності тих, хто має їх Аотримуватися; закони повинні бути віАносно постійними; повинна існувати відповіАність між формумюванням законів та їхнім реацьним застосуванням. ${ }^{5}$

3 вісімнаАцяти елементів («принципів») верховенства права, виокремлених американським правознавцем, професором Корнельської школи права Робертом С. Саммерсом,

\footnotetext{
${ }^{3}$ Станіскав Погребняк, Основопояожні принципи права (змістовна характеристика) (Харків: Право, 2008), 178-92.

${ }^{4}$ Friedrich August von Hayek, The Road to Serfdom: text and documents, ed. Bruce Caldwell. Definitive ed. (London: The University of Chicago press, 2007), 112-23.

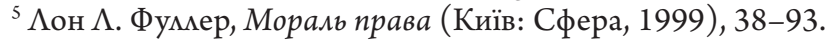


принаймні дев’ять або є складовими правової визначеності, або спрямовані на їі прищеплення націонацьною правовою системою: чіткість та простота застосування критерію визначення належного уповноваження; чіткість та визначеність усіх законів; їня Аоступність (письмова форма, офіційне обнародування); заборона зворотної Аї̈; виконуваність; стабільність (незмінюваність); заздалегідь відомі органи та процедура правових змін; єАність тлумачення та застосування права; наявність зазАацегіАь віАомих засобів правового захисту та насліАків невиконання правових вимог. 6

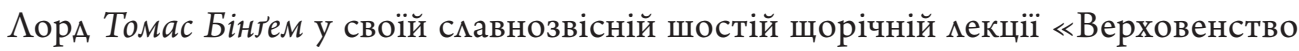
права», що була прочитана 16 мистопада 2006 р. на честь віце-ректора КембриАжського університету сера А. Вільямса, стрижнем принципу верховенства права визначає те, «що всі особи та органи влаАи в Аержаві, як публічні, так і приватні, мають бути зв'язані та мати право користуватися законами, що є віАкрито проголошеними, зорієнтованими на майбутнє та відкрито застосовуються в судах», тобто законність і правову визначеність. Згідно з першим із восьми піАправиц, які, за Бінгемом, становцять зміст верховенства права, «закон має бути Аоступним та, наскільки це можливо, зрозумілим, ясним і передбачуваним $\gg .{ }^{7}$

Запропоноване Бінгемом визначення верховенства права було визнане Європейською комісією «За Аемократію через право» (Венеційською комісією) у Аоповіді про верховенство права, схваменій на 86-му пленарному засіданні 25-26 березня 2011 р., таким, що «найкраще охоплює головні елементи поняття “верховенство права” ». У цій Аоповіді Комісія зазначила, що однією зі складових верховенства права є правова визначеність; вона вимагає, щоб правові норми були чіткими й точними, спрямованими на те, щоб забезпечити постійну прогнозованість ситуацій правовіАносин, що виникають (пп. 41, 46 АоповіАі).

У Контрольному переліку питань для оцінки дотримання верховенства права (Rие of Law Checklist), прийнятому на 106-му пленарному засіданні 11-12 березня 2016 р., 9 Венеційська комісія виокремима вісім складових принципу правової визначеності (звісно, цей перелік не претендує на вичерпність, не обмежує й не замінює собою розвіАки наукової та судової Аоктрин - власне, як і сам перелік вимог верховенства права у АоповіАі):

\footnotetext{
${ }^{6}$ Robert S. Summers, “The Principles of the Rule of Law," Notre Dame Law Review 74 (1999): 1691-712. ${ }^{7}$ Томас Бінгем, “Верховенство права," http://legalitas.com.ua/ua/ukr-t-bin\%D2\%91em-verxovenstvo-prava/. ${ }^{8}$ Верховенство права, АоповіАь № 512/2009 (Венеційська комісія, Страсбург, 4 квітня 2011 р.), https://www.venice.coe.int/webforms/documents/default.aspx?pdffile=CDL-AD(2011)003rev-ukr. ${ }^{9}$ Rule of Law Checklist, Study no. 711/2013 (Venice Commission, Strasbourg, 18 March 2016), https://www.venice.coe.int/webforms/documents/default.aspx?pdffile=CDL-AD(2016)007-e. Цей документ на замовлення Програми агентства США з міжнародного розвиткку (USAID) реформування сектору юстиції «Нове правосуААя» переклаАено українською мовою професором Сергієм Головатим і виАано піА назвою «Мірило правовлаААя».
} 
1. Аоступність законодавства, у тому числі оприлюднення законодавчих актів переА набранням ними чинності, мегкий Аоступ до них, наприклаА, через безкоштовний Інтернет та/або в офіційних виданнях.

2. Аоступність судових рішень аля суспільства, у тому числі обгрунтованість винятків із цього (обмеження можуть бути виправАаними, якщо їхньою метою $є$ захист прав особи, - наприклаА, прав неповнолітніх у кримінальних справах).

3. Передбачуваність правових актів, у тому числі передбачуваність наслінків приписів права, зрозумілий спосіб викладення правових актів, чіткість вказівок нового акта на скасування або зміну попереднього. Передбачуваність означає не мише те, що приписи правових актів мають бути (Ае можливо) проголошеними ще Ао їхньої імплементації, а й що вони мають бути переАбачуваними за своїми насліАками: їх має бути сформульовано з достатньою чіткістю та зрозумікістю, аби суб'єкти права мали змогу впорядкувати свою поведінку згідно з ними (рішення Європейського суду з прав Аюдини віА 26 квітня 1979 р. у справі «Санді Таймс» проти Сполученого Королівства ${ }^{10}$ ). Згідно з усталеною практикою ЄСП (рішення у справах Реквеньї проти Угорщини, «Санді Таймс» проти Сполученого Королівства, Коккінакіс проти Греції, Бесарабська Митрополія проти Молдови тощо) однією з вимог, що випливає зі слів «встановлений законом», $\epsilon$ вимога передбачуваності: норма не може вважатися «законом», якщо їі не сформульовано з достатньою чіткістю, яка дає громадянинові змогу керуватися иією нормою у своїх діях.

4. Сталість і послідовність приписів правових актів. Брак цього може вплинути на спроможність особи планувати свої дії. Проте сталість не є самоцілюю: приписам права має бути властивою спроможність пристосовуватись до умов, що змінюються. Приписи права можна змінювати, утім за умов, що суспільство знає про це напереА і бере участь в обговоренні, а також що не буде шкіАливих наслідків Аля мегітимних очікувань. ${ }^{11}$

Принцип правової визначеності, крім іншого, означає стабільність та єАність судової практики, можливість віАступу судом віА своєї попереАньої позиції ишее за наявності вагомих підстав. Елементом правової визначеності є принцип єдності судової практики, який полягає у забезпеченні оАнакового правозастосування в судочинстві, що сприяє передбачуваності щодо вирішення спорів між учасниками судового процесу.

Принцип єАності судової практики не має абсолютного характеру. НаприклаА, процесуальним законодавством України Велика Палата Верховного Суду, об'єАнані палати, палати касаційних суАів Верховного Суду наАілені виключними повноваженнями у встановленому порядку відступати віА раніше сформованої правової позиції. Такі повноваження наАано з огляду на те, що в протилежному випадку це, nо-перще, означало 6 неможливість виправлення судом своєї власної передчасної або

\footnotetext{
${ }^{10}$ The Sunday Times v. the United Kingdom (no. 1), 26 April 1979, Series A no. 30.

${ }^{11}$ Мірило правовладдя. Коментар. Гıосарій. Rule of Law Checklist, пер. Сергія Головатого (USAID, 2017), 23.
} 
«застарілої» позиції, викликаної, зокрема, нечіткістю закону (невідповідності критерію «якість закону»), що призвела до неоднакового тлумачення норм права, а по-друге, виключало б можливість Аинамічного розвитку суспільних правовіАносин та права. За певних обставин віАступ віА попереАніх правових позицій суду касаційної інстанції УзгоАжується з усталеним правовим піАходом, згіАно з яким у разі конкуренції між правдою (правильністю) і стабільністю пріоритет варто віАдавати першій («truth or stability - truth is preferable»).

Амя узгодження загального Аля всієї правової системи принципу правової визначеності та спеціальних концепцій «Аинамічного тлумачення» та «розвитку права» у рішеннях ЄСП $\Lambda$ та, частково, Великої Памати Верховного Суду сформувалася стала практика, віАповіАно Ао якої віАступ віА правової позиції повинен мати тільки вагомі піАстави, реальне піАгрунтя, тобто суА не повинен віАступати віА попереАніх рішень за віАсутності належної Аля цього причини; метою віАступу може слугувати виправлення мише тих неузгодженостей (помилок), що мають фунАаментальне значення Аля суаової системи та їі розвитку.

Обгрунтованими піАставами Амя віАступу віА уже сформованої правової позиції Верховного Суау є передусім:

1) зміна законодавства (існують випадки, за яких зміна законодавства не дозволяє сУАу оАнозначно Аійти висновку, що зміна суАової практики можиива без віАступу віА раніше сформованої правової позиції);

2) ухвалення рішення Конституційним Судом України;

3) нечіткість закону (невідповіАності до критерію «якість закону»), що призвело Ао різного тлумачення судами (палатами, колегіями) норм права;

4) винесення рішення $Є С П \Lambda$, висновки якого мають бути враховані націонацьними суАами;

5) зміни у праворозумінні, зумовлені: розширенням сфери застосування певного принципу права; зміною Аоктринальних піАходів Ао вирішення склаАних питань у певних сферах суспільно-управлінських віАносин; наявністю загрози національній безпеці; змінами у фінансових можливостях держави. ${ }^{12}$

5. Аегітимні очікування (legitimate expectations). На цей час єАиної Аоктрини мегітимних очікувань, придатної Амя всіх національних правопорядків, немає. Вважається, що принцип мегітимних очікувань «походить віА німецького принципу Vertrauenschutz («захист Аовіри»), метою якого є забезпечення того, щоб кожен, хто має Аовіру Ао мегальності рішень і Аій публічної аАміністрації, піАлягав захисту. Принцип

\footnotetext{
${ }^{12}$ Ян Берназюк, “Співвідношення необхідності забезпечення єАності судової практики та відступу віА правових позицій Верховного Суду (на приклаАі вирішення публічно-правових спорів),” Судебно-юридическал газета, 26 серпня 2020, https://sud.ua/ru/news/blog/177404-spivvidnoshennyaneobkhidnosti-zabezpechennya-yednosti-sudovoyi-praktiki-ta-vidstupu-vid-pravovikh-pozitsiyverkhovnogo-sudu-na-prikladi-virishennya-publichno-pravovikh-sporiv?fbclid=IwAR2D9EastZc6_ic oWnIGyUwMUIzxKUw2X1w3RWPgdg7LEoQuV798suRpCHg.
} 
Vertrauenschutz німецького аАміністративного права, у свою чергу, запозичений з німецького приватно-правового принципу правового захисту Аобросовісних Аій (bona fide acts), закріпленому в цивільному законодавстві ». ${ }^{13}$

Принцип легітимних очікувань (або «захисту мегітимних очікувань») є складовою загального принципу правової визначеності у праві ЄС. Він відбиває іАею, що органи публічної влади повинні не мише Аотримуватися приписів правових актів, а й своїх обіцянок та пробуАжених очікувань. ЗгіАно з доктриною легітимних очікувань ті, хто чинить добросовісно на піАставі права, яким воно $є$, не повинні віАчувати краху наАій щодо своїх мегітимних очікувань. Утім нові ситуації можуть бути достатньою піАставою Аля законодавчих змін, що спричиняють виникнення відчуття краху мегітимних очікувань у виняткових випадках. Така доктрина застосовна не мише до законодавства, а й до рішень індивідуального характеру, що їх ухвалюють органи публічної влаАи.

Розуміння «легітимних очікувань саме як елемента правової визначеності втілилося у практиці Суду СС, який у рішенні віА 12 мистопада 1981 р. у справі Amministrazione delle finanze dello Stato $v$ Srl Meridionale Industria Salumi and others ${ }^{14}$ наголосив, що Аія (насліАки) права Співтовариства має бути чіткою й передбачуваною Аля тих, на кого воно поширюється. Аалі СуА послався на свої попереАні рішення у справах Racke v Hauptzollamt Mainz (1979) та Hauptzollamt Landau (1979), у яких він неодноразово підкреслював важливість принципів правової визначеності та мегітимних очікувань, а також вказав, що «принцип правової визначеності покликаний запобігати випадкам набрання чинності положеннями законодавства Співтовариства до моменту їх публікації, і що така можливість $є$ винятковою, коли це обумовлено цілями віАповіАного законодавства та у випадку, якщо мегітимні очікування тих, на кого воно поширюється, належним чином забезпечені ${ }^{15}$

Практикою Суду ЄС та ЄСП $\Lambda$ мегітимні очікування розглядаються як елемент правової визначеності, у тому числі й тоді, коли йдеться про захист таких очікувань щодо зАійснення права власності й саме у зв' язку з автономними поняттями майна та власності. ЄСП $\Lambda$ конструкцію «легітимні очікування» використовував у своїй практиці неодноразово. НаприклаА, згіАно з усталеною правовою позицією Суду існування заборгованості, визнаної остаточними та обов'язковими Аля виконання судовими рішеннями, налає особі, на користь якої таке рішення було винесено, «легітимне очікування», що заборгованість буде виплачено, аАже вона становить «майно» такої особи в розумінні ст. 1 Першого протоколу до Конвенції про захист прав АюАини і основоположних свобод. Скасування такого рішення прирівнюється до порушення

\footnotetext{
13 Һюдмила Богачова, “Принцип правової визначеності в європейському і національному праві (змістовна характеристика)," Теорія і практика правознавства 2 (2013), http://nbuv.gov.ua/UJRN/ tipp_2013_2_74.

${ }^{14}$ Cases $21 \overline{2}$ to 217/80 Amministrazione delle Finanze dello Stato v Salumi [1981] ECR 1981/8/2735.

${ }^{15}$ Олена Бемяневич, “Поняття мегітимних очікувань та проблеми його застосування судами України,” Приватне право і підприємництво 16 (2016): 41-45.
} 
права на мирне володіння майном, оскільки процесуальні норми створюються Аля забезпечення належного зАійснення правосуААя та Аотримання принципу правової визначеності, й сторони провадження повинні мати право очікувати застосування норм (Аив., зокрема, рішення віА 3 квітня 2008 р. у справі Пономарьов проти Украӥни, ${ }^{16}$ віА 6 жовтня 2011 р. Агрокомплекс проти України ${ }^{17}$ ). У рішенні ЄСП А віА 29 мистопаАа 2005 р. у справі Суханов та Ільченко проти України ${ }^{18}$ зазначено, що за певних обставин «законне сподівання» на отримання «активу» також може захищатися ст. 1 Першого протоколу. Так, якщо суть вимоги особи пов'язана з майновим правом, особа, якій воно надане, може вважатися такою, що має «законне сподівання», якщо Аця такого права у національному законодавстві існує достатнє піАгрунтя - наприклаА, коли є усталена практика національних судів, якою піАтверАжується його існування (Аив. рішення Великої Палати ЄСП А віА 28 вересня 2004 р. у справі Копеиький проти Словаччини ${ }^{19}$ ). Проте не можна стверджувати про наявність законного сподівання, якщо існує спір щодо правильного тлумачення та застосування національного законодавства і вимоги заявника згодом віАхимяються національними судами. У рішенні $Є С П \Lambda$ віА 1 червня 2006 р. у справі Федоренко проти України ${ }^{20}$ зазначено, що заявник мав щонайменше «законні сподівання» на АохіА віАповіАно Ао пункту Аоговору про Аоларовий еквівалент суми в гривні, і це сподівання може вважатися «майном» у розумінні ст. 1 Першого протоколу. ЄСП $\Lambda$ також констатував, що Аії управління юстиції можна розцінити як такі, що звели нанівець «законні сподівання» заявника за договором і позбавили його, зокрема, умови, на яку він погодився піА час уклаАання Аоговору.

У рішенні ЄСП $\Lambda$ віА 24 червня 2003 р. у справі Стретч проти Сполученого Королівства ${ }^{21}$ законними вважаються «очікування на законних підставах продовження терміну Аії договору оренди, і це очікування $є$ складовою частиною права власності заявника, наданого йому за договором оренди в розумінні зазначеної статті». СуА Аійшов висновку про те, що «заявник мав право, принаймні, очікувати на законних підставах, що він зможе продовжити термін Аії договору, і таке очікування можна вважати - в цілях застосування положень ст. 1 Першого протоколу - складовою його права власності, наданого йому за договором оренди».

ОАним з інструментів захисту мегітимних очікувань у практиці ЄСП $\Lambda € \kappa$ концепція автономного тлумачення, згіАно з якою СуА у свойй практиці з метою забезпечення іiї визначеності формулює автономні понятmя - основні юридичні терміни, що за змістом та обсягом тлумачення $є$ оАнаковими Аля застосування в усіх справах Суду, незалежно віА їхнього значення та інтерпретації в національних правових системах

\footnotetext{
${ }^{16}$ Ponomaryov v. Ukraine, no. 3236/03, 3 April 2008.

${ }^{17}$ Agrokompleks v. Ukraine, no. 23465/03, 6 October 2011.

${ }^{18}$ Ilchenko v. Ukraine, no. 17303/03, 29 November 2005.

${ }^{19}$ Kopecký v. Slovakia, no. 44912/98, 7 January 2003.

${ }^{20}$ Fedorenko v. Ukraine, no. 25921/02, 1 June 2006.

${ }^{21}$ Stretch v. the United Kingdom, no. 44277/98, 24 June 2003.
} 
Аержав - учасниць Конвенції. Це такі юридичні поняття, як «майно» (ст. 1 Першого протоколу), «закон», власне, «легітимні очікування», тощо. Так, практика ЄСП визнає майном «права на речі та майно (права in rem та права in personam); існуючі володіння або фактично існуючі права власності; вимоги, борги та звернення на певне майно; економічні, комерційні, піАприємницькі та професійні інтереси; Аозволи та міцензії; пенсії та соціальні виплати (за певних умов); спадкові права та правонаступництво; майно - власність юридичних осіб, асоціацій, компаній, власників акцій; права та інтереси акціонерів; інші права власників». ${ }^{22}$

Також автономним поняттям ЄСП $\Lambda$ визначає «закон», визнаючи, що до змісту цього поняття входять норми права, які створюються не Аише законодавчою та виконавчою владами, але й, що найважливіше, судами (рішення віА 26 квітня 1979 р. у справі «Санді Таймс» проти Сполученого Королівства $\left.{ }^{23}\right)$. Посилання держави на право ЄС чи міжнародне право буде прийняте як належна правова підстава за умови, що віАповіАна норма узгоджується з концепцією «закону», що міститься в Конвенції. У цьому ж рішенні СуА визначив два додаткових критерії, яким повинна відповідати норма права, щуоб вважатися «законом»:

nо-перше, норма права мусить бути належним чином Аоступною: особи повинні мати віАповіАну Ао обставин можливість орієнтуватися в тому, які правові норми застосовуються в конкретному випалку;

nо-друге, норма права не може вважатися «законом», якщо їі не сформульовано 3 Аостатнім ступенем точності, що Аозволяє громадянинові узгоджувати з нею свою поведінку.

Таким чином, характеристика очікувань як мегітимних поєАнує в собі: по-перше, їхню законність, яка зумовлена реалізацією особою належного їй суб'єктивного права; по-друге, їхню облрунтованість, тобто зумовлену законом раціональність сподівань учасників суспільних віАносин. ${ }^{24}$

6. Унеможливлення зворотної (ретроактивної) дї правових актів, передусім, але не виключно, кримінацьного законодавства, у тому числі чітко визначені винятки із заборони зворотної Аії (передусім у разі пом'якшення чи скасування кримінальної віАповіАальності).

7. Принииии nullum crimen sine lege ma nullum poena sine lege («немає закону - немає злочину», «немає закону - немає покарання )).

8. Принции (правило) res judicata (скорочення віА Аавньоримського юриАичного правима «res judicata pro veritate habetur!» - 3 матин. «судове рішення визнається за істину»), що вимагає поваги Ао остаточного рішення суду й забороняє перегляА остаточного та обов' язкового Ао виконання судового рішення Аише з метою Аомогтися повторного розгляду та винесення нового рішення у справі - Аив., зокрема, рішення

\footnotetext{
${ }^{22}$ Бемяневич, "Поняття мегітимних очікувань," 42.

${ }^{23}$ The Sunday Times $v$. the United Kingdom (no. 1).

${ }^{24}$ Бемяневич, “Поняття мегітимних очікувань," 42.
} 


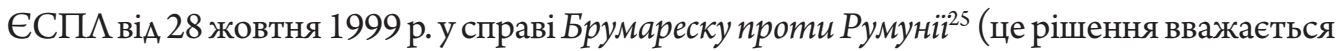
провіАним у закріпленні у практиці ЄСП $А$ вимоги правової визначеності, зокрема

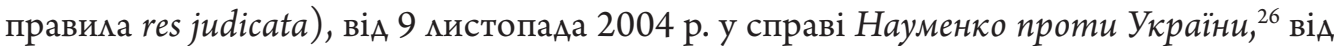
3 квітня 2008 р. у справі Пономарьов проти Украйни, ${ }^{27}$ віА 19 кютого 2009 р. у справі Христов проти України. ${ }^{28}$

За правимом res judicata, остаточне судове рішення має виконуватися та, як правило, не може бути переглянуте, зокрема за заявою прокурорів чи голів вищих судів у поряАку нагляду (що було сталою практикою в раАянській та інших соціалістичних правових системах, а також в Україні у перші роки незалежності), повноваження судів вищого рівня з перегляду мають зАійснюватися виключно Аля виправлення суАових помилок та недоліків. Коли за апеляційною скаргою винесено остаточне рішення, то подальші звернення в апемяційному порядку неможливі. САіА визнавати остаточні рішення й Аотримуватися їх, за винятком випаАків, коли $€$ незаперечні піАстави Аля їхнього перегляау. BiАхіА віА res judicata можмивий мише тоАі, коли цього вимагають віАповіАні вагомі й непереборні обставини.

В установчих Аоговорах $С С$ принцип правової визначеності не закріплюється, проте Судом ЄС він визнається одним із загальних принципів європейського права. Цей принцип Аля обгрунтування своїх рішень використовує і ЄСП А. Аналіз його практики Аозволяє виокремити три групи вимог, які включає принцип правової визначеності: 1) вимоги до визначеності законодавства; 2) вимоги до визначеності повноважень; 3) вимоги до визначеності судових рішень.

Так, у рішенні віА 23 вересня 1998 р. у справі Стіл та інші проти Сполученого Королівства ${ }^{29}$ СуА вказав, що вимога п. 2 ст. 10 Конвенції про те, що обмеження зАійснення свободи вираження погмядів, яке має бути встановлене законом, $є$ рівнозначною вимозі, передбаченій у п. 1 ст. 5 про те, що буАь-яке позбавлення свободи має бути законним. СуА наголошує: Конвенція вимагає, щоб усе право, чи то писане, чи неписане, було Аостатньо чітким, щоб дозволити громадянинові, якщо виникне потреба з належною порадою, передбачати певною мірою за певних обставин насліАки, які може спричинити певна Аія. Вислови «законний» та «згіАно 3 процеАурою, встановценою законом», у пункті 1 ст. 5 зумовцюють не мише повне дотримання основних процесуальних норм внутрішньодержавного права, а й те, що будь-яке позбавлення свободи відповідає меті ст. 5 і не є свавільним.

У рішенні віА 25 мистопада 1999 р. у справі Гешмен і Герруп проти Сполученого Королівства ${ }^{30}$ СуА вказав, що однією з вимог, яка випливає зі словосполучення

\footnotetext{
${ }^{25}$ Brumărescu v. Romania [GC] , no. 28342/95, ECHR 1999-VII.

${ }^{26}$ Naumenko v. Ukraine, no. 42023/98, 10 February 2004.

${ }^{27}$ Ponomaryov v. Ukraine, no. 3236/03, 3 April 2008.

${ }^{28}$ Khristov v. Ukraine, no. 24465/04, 19 February 2009.

${ }^{29}$ Steel and Others v. the United Kingdom, 23 September 1998, Reports of Judgments and Decisions 1998-VII.

${ }^{30}$ Hashman and Harrup v. the United Kingdom [GC], no. 25594/94, ECHR 1999-VIII.
} 
«встановлений законом», є переАбачуваність. Норму не можна вважати «законом», якщо їі не сформульовано достатньо чітко, що Аає особі можливість керуватися цією нормою у своїх Аіях. Та хоча визначеність у законі надзвичайно бажана, забезпечення їі може призвести до надмірної ригіАності (незАатності до змін, негнучкості), тоді як закон ніколи не повинен віАставати віА обставин, що змінюються. Ступінь чіткості, яку мають забезпечувати формулювання національних законів і яка в жодному випаАку не може охопити всі непередбачувані обставини, значною мірою залежить віА змісту певного Аокумента, сфери, на яку поширюється закон, а також віА кількості та статусу тих, кому він аАресований.

У рішенні віА 10 мютого 2004 р. у справі Пухк проти Естонії ${ }^{31}$ СуА зазначив, що ст. 7 Конвенції не обмежується забороною ретроспективного застосування кримінацьного законодавства на шкоду обвинуваченому; вона також втілює загалом принцип, що тільки закон може визначити кримінальне правопорушення та встановити покарання (nullum crime nulla poena sine lege), а також принцип, за яким кримінальне право не повинно надмірно тлумачитися на шкоду обвинуваченому. 3 цих принципів випливає, що правопорушення має бути чітко встановцено в законі. Цю вимогу Аотримано, якщо особа може Аізнатися на основі формулювання віАповіАного положення та, у разі потреби, за Аопомогою його судового тлумачення, які Аї чи безАіяльність $\epsilon$ піАставою Аля кримінальної віАповіАальності. ${ }^{32}$

ЄСП А неодноразово звертав увагу на неАосконацість законодавства України та необхіАність Аотримуватися принципу правової визначеності. Так, у рішенні віА 6 мистопада 2008 р. у справі Єлоєв проти України ${ }^{33}$ Суд зазначив, що віАсутність чітко сформульованих положень, які б визначали, чи можливо належним чином продовжити (якщо так, то за яких умов) застосування на стадії судового сліАства запобіжного заходу у вигляді тримання піА вартою, обраного на визначений період на стаАії Аосудового сліАства, не віАповіАає критерію «передбачуваності закону». СуА також нагаАав, що практика, яка виникла у зв' язку із законодавчою прогалиною і яка зумовлює тримання особи піА вартою протягом необмеженого й непередбачуваного строку за обставин, коли таке тримання не передбачається ні конкретним положенням законодавства, ні будь-яким судовим рішенням, сама по собі суперечить принципу правової визначеності, який $є$ оАним $з$ основних елементів верховенства права. ${ }^{34}$

Пробцема неухицьного та оперативного виконання судових рішень як необхіАна умова правової визначеності та верховенства права загалом є Ауже актуацьною та болісною Аля України, на що неодноразово вказував ЄСПА. Так, Вемика Палата

\footnotetext{
${ }^{31}$ Puhk v. Estonia, no. 55103/00, 10 February 2004.

${ }^{32}$ Юлія Матвєєва, “Правова визначеність та судАівське правотворення,” Наук. записки наи. ун-ту

"Києво-Могилянська академіл”, Т. 103: Юридичні науки (Київ, 2010), 51-52.

${ }^{33}$ Yeloyev v. Ukraine, no. 17283/02, 6 November 2008.

${ }^{34}$ Богачова, “Принцип правової визначеності.”
} 
ЄСП у у рішенні віА 12 жовтня 2017 р. у справі Бурмич та інші проти України щодо тривалого невиконання рішень українських суАів наголосила, що з часу «пімотного» рішення віА 15 жовтня 2009 р. у справі Юрій Миколайович Іванов проти Украӥни Україна не зробила нічого, аби вирішити проблему, - кількість поАібних скарг до ЄСП $\Lambda$ иише зросла. СуА віАзначив, що він уже виконав свою роль у цій справі, а саме: ілентифікував системну проблему, констатував порушення права на справеАливий суА і наАав вказівки щодо заходів, Ао яких сліА вАатися Україні. Суа не вбачає своєї подальшої ролі у вирішенні питання, а повторення тих самих висновків Суау в тисячах поАібних справ не вирішить проблему. ЄСП п прийняв унікальне рішення у цій справі: не розгляАаючи 12143 справи, переАав їх Ао Комітету Міністрів РаАи Європи, аби останній разом з Урядом України знайшли вирішення цієї системної проблеми. Усі нові скарги до СуАу з цього питання оАразу передаватимуться до Комітету Міністрів.

ЄСП А наголошує на зв'язку між приниипами правової визначеності та законності. Так, у рішенні Вемикої Палати віА 29 березня 2010 р. у справі Медведєв та інші проти Франиії ${ }^{36}$ Суд зазначив: «НаАзвичайно важливе значення має, що умови Аля позбавлення волі віАповіАно до внутрішньодержавного та (або) міжнародного права мусять бути чітко визначені й що сам закон повинен бути переАбачуваним у своєму застосуванні, так щоб він відповіАав стандартові «законності», встановленому Конвенцією, - стандартові, який вимагає, щоб усе законодавство було Аостатньо точним з метою уникнути буАь-якого ризику та свавілАя й Аозволити громаАянинові, за необхідністю за допомогою віАповідної консумьтації, передбачити розумною за обставин справи мірою насліАки, які ця Аія може тягти за собою».

У рішенні віА 18 груаня 2008 р. у справі Новік проти Украйни ${ }^{37}$ Суа піАкреслив, що «коли йАеться про позбавлення свобоАи, наАзвичайно важливою умовою $\epsilon$ забезпечення загального принципу правової визначеності. Вимога “якості закону” У розумінні п. 1 ст. 5 Конвенції означає, що коли національний закон переАбачає можливість позбавлення свободи, такий закон має бути Аостатньо Аоступним, чітко сформульованим і передбачуваним у своєму застосуванні Аля того, щоб виключити буАь-який ризик свавілмя». ${ }^{38}$

Значущість принципу правової визначеності Аля результативного правового регумювання підтверАжується і практикою Конституційного Суду України. Суд застосував цей принцип як невіА’ємну вимогу верховенства права у низці справ: у рішенні віА 22 вересня 2005 р. у справі про постійне користування земельними ділянками ${ }^{39}$ («із

\footnotetext{
${ }^{35}$ Burmych and Others v. Ukraine (striking out) [GC], nos. 46852/13 et al, 12 October 2017.

${ }^{36}$ Medvedyev and Others v. France [GC], no. 3394/03, ECHR 2010.

${ }^{37}$ Novik v. Ukraine, no. 48068/06, 18 December 2008.

38 Також див. вищенаведену правову позицію ЄСП щ щодо автономного поняття «закон», сформульовану в рішенні віА 26 квітня 1979 р. у справі The Sunday Times v. the United Kingdom.

39 Рішення Конституційного Суду України віА 22.09.2005 № 5-рп/2005 (№ 1-17/2005).
} 
конституційних принципів рівності і справедливості випливає вимога визначеності, ясності і неАвозначності правової норми, оскільки інше не може забезпечити ії оАнакове застосування, не виключає необмеженості трактування у правозастосовній практиці і неминуче призводить Ао сваволі ) ); у рішенні віА 29 червня 2010 р. у справі за конституційним поданням Уповноваженого Верховної Ради Украйни з прав ююдини щодо відповідності Конституијї Украӥни (конституційності) абзацу восвмого пункту 5 частини першої статті 11 Закону України «Про міліцію» ${ }^{40}$ («ОАним із елементів верховенства права є принцип правової визначеності, у якому стверджується, що обмеження основних прав мюАини та громаАянина і втілення цих обмежень на практиці Аопустиме мише за умови забезпечення передбачуваності застосування правових норм, встановлюваних такими обмеженнями»); у рішенні віА 11 березня 2010 р. у справі за конституційним поданням 46 народних депутатів України щзодо офічійного тлумачення термінів «найвищий судовий орган», «вищий судовий орган», «касаційне оскарження», які містяться у статтях 125, 129 Конституијї України ${ }^{41}$ (mym Суд використав правимо res judicata, зазначивши, що наявність Авох касаційних інстанцій Аля перевірки рішень спеціалізованих судів не віАповіАає засаАам правової визначеності), тощо. ${ }^{42}$

Водночас у низці своїх рішень Конституційний СуА України, на нашу аумку, знехтував принципом правової визначеності (й верховенства права загалом). СереА них Аостатньо згаАати такі:

рішення віА 25 груаня 2003 р. у справі щодо строків перебування на посту Президента України, ${ }^{43}$ згіАно $з$ яким положення частини третьої статті 103 Конституції України, за яким одна й та сама особа не може бути Президентом України більше ніж Ава строки піАряА, треба розуміти так, що це положення поширюється мише на осіб, яких обирають на пост Президента України після набуття чинності Конституцією України 1996 р. Особа, яку вперше було обрано Президентом України за чинною Конституцією України в 1999 р., має право балотуватися на чергових виборах Президента України у 2004 р. (так зване «рішення про третій строк»);

рішення віА 19 вересня 2012 р. у справі за конституційним зверненням приватного піАприємства «IКIO» щодо офіційного тлумачення положення частини першої статті 61 Сімейного кодексу України, ${ }^{44}$ згідно з яким це положення треба розуміти так, що статутний капітал та майно приватного піАприємства $є$ об’єктом права спільної сумісної власності подружжя (а не самого підприємства - як це прямо зазначено в Цивільному колексі України та віАповіАає сталій доктрині цивільного права);

\footnotetext{
$\overline{40}$ Рішення Конституційного Суду України віА 29.06.2010 № 17-рп/2010 (№ 1-25/2010).

${ }^{41}$ Рішення Конституційного Суду України віА 11.03.2010 № 8-рп/2010 (№ 1-1/2010).

${ }^{42}$ Аокладніше див.: Богачова, “Принцип правової визначеності."

${ }^{43}$ Рішення Конституційного Суду України віА 25.12.2003 № 22-рп/2003 (№ 1-46/2003).

${ }^{44}$ Рішення Конституційного СуАу України віА 19.09.2012 № 17-рп/2012 (№ 1-8/2012).
} 
рішення віА 9 мютого 1999 р. у справі про зворотну Аію в часі законів та інших нормативно-правових актів, ${ }^{45}$ згіАно з яким положення частини першої ст. 58 Конституції України про те, що закони та інші нормативно-правові акти не мають зворотної Аії в часі, крім випадків, коли вони пом' якшують або скасовують відповіАальність особи, треба розуміти так, що воно стосується мюАини і громаАянина (фізичної особи) (що внесло хаос невизначеності в судову практику аАміністративних судів, зокрема в податкових справах);

рішення віА 15 березня 2016 р. у справі за конституційним поАанням 51 народного Аепутата України щодо офіційного тмумачення положення «на наступній черговій сесії Верховної РаАи України», яке міститься у статті 155 Конституції України, ${ }^{46}$ згіАно з яким положення «на наступній черговій сесії Верховної РаАи України», застосоване у ст. 155 Конституції України, необхіАно розуміти так, що наступною черговою сесією Верховної РаАи України є чергова сесія парламенту, яка має віАбутися віАповіАно Ао положень розАілу XIII «Внесення змін до Конституції України» Основного Закону України та Регламенту Верховної РаАи України (тобто «наступною черговою» може бути визначено будь-яку сесію, а не обов'язково наступну чергову з точки зору зАорового глузАу та передбачуваного мексичного тлумачення);

рішення віА 2 грудня 2019 р. у справі за конституційним поданням 49 народних Аепутатів України щодо офіційного тлумачення положень статті $151^{2}$ Конституції України, ${ }^{47}$ згіАно з яким рішення КСУ безвіАносно Ао їх юридичної форми, ухвалені 3 питань його викмючних конституційних повноважень, не можуть бути оскаржені (що явмяє собою, по-перше, необгрунтоване розширене тлумачення конституційного терміна «рішення КСУ», по-Аруге, фактичне втручання в зАійснення правосуААя в конкретній адміністративній справі, у якій КСУ виступав як віАповіАач та в якій уже було ухвалене рішення першої інстанції про задоволення позову, й по-третє, $\epsilon$ «рішенням у вмасній справі»).

На наше переконання, такі обов'язкові й остаточні рішення органу конституційної юстиції посилюють у юридичної спільноти та в суспільства загалом недовіру до безсторонності та неупереАженості судової системи, що негативно впииває на рівень ії мегітимності та, як насліАок, на ефективність національної правової системи.

ВіАбиттям вимоги правової визначеності в американському конституційному праві $\epsilon$ доктрина невизначеності закону (doctrine of uncertainty of the law), згіАно з якою закон $\epsilon$ нечинним, якщо він $\epsilon$ занаАто розпливчастим Аля розуміння пересічним громаАянином. $€$ кілька причин, за якими закон може вважатися невизначеним; загалом закон може бути названий недійсним із причин невизначеності, коми пересічний громаАянин не може в цілому визначити, які особи регулюються законом, яку повеАінку заборонено,

\footnotetext{
${ }_{45}$ Рішення Конституційного Суду України віА 09.02.1999 № 1-рп/99 (№ 1-7/99).

${ }^{46}$ Рішення Конституційного Суду України віА 15.03.2016 № 1-рп/2016 (№ 1-21/2016).

${ }^{47}$ Рішення Конституційного СуАу України віА 02.12.2019 № 11-р/2019 (№ 1-182/2019(4165/19)).
} 
а також те, яке покарання може бути призначено. Кримінальні закони, які, наприклаА, не стверджують явно і виразно, яка поведінка заслуговує на покарання, є недійсними через невизначеність. Закон $є$ також неАійсним через невизначеність, якщо законодавчий орган передає судАям та/або посадовим особам повноваження настільки широкі, що це може призвести Ао необгрунтованого кримінального переслідування. Пов' язаним із «недійсністю через невизначеність» $€$ поняття «неконституційної невизначеності».

За цією Аоктриною критеріями, яким повинні віАповіАати закони, щоб вважатися конституційними, є такі:

nо-перше, закон повинен прямо встановмювати, що він наказує й що піАцягає виконанню;

nо-друге, повинно бути надано визначення потенційно розпливчастих висловлювань.

У справі Коннеллі проти Головної будівельної компанії (рішення було ухвалено 4 січня 1926 р.) суаАя Верховного Суау США АжорАж СазерленА виклав Аоктрину невизначеності так:

Те, що формулювання кримінального закону, яким встановлюється новий злочин, повинні бути достатньо ясними Аля того, аби дати зрозуміти тим, хто піАпадає піА їхню Аію, яка їхня поведінка матиме наслідком відповіАальність за цим законом, $є$ загальновизнаною вимогою, співзвучною пересічним поняттям справеАливих правим гри і встановлених норм права. Тому закон, який забороняє чи вимагає вчинення дії у формулюваннях настільки нечітких, що Аюдина загальних розумових зАібностей повинна гаАати, який його зміст, і зАогадуватися щодо його застосування, порушує перший принцип належної правової процеАури. ${ }^{48}$

Випадками, за яких закон може бути оскаржено як неконституційно невизначений, $€$ передусім такі:

1) коли закон не перераховує конкретно варіантів повеАінки, які є обов'язковими або забороненими. У такому випадку пересічний громаАянин не знає, чого конкретно вимагає закон;

2) коли закон конкретно не Аеталізує процедури, яких дотримуються посадові особи або суААі, які розглядають справу. Як запобігання закон повинен особциво Аокладно розповіАати, що посадові особи мають робити, встановлюючи як те, що вони повинні робити, так і те, чого не повинні робити. СуААі повинні, віАповіАно Ао Аоктрини, мати чітке уявлення про те, яким чином вони будуть вести справу.

Так, Верховний СуА ФцориАи у рішенні віА 17 грудня 1971 р. у справі Альва Ажин Франклін проти штату Флорида ${ }^{49}$ постановив, що Аержавна заборона на тяжкий кримінальний змочин, содомію, була неконституційно розпливчастою, тому що пересічна мюдина звичайного інтелекту не могла певно знати, не робцячи припущень,

\footnotetext{
${ }^{48}$ Цит. за: Окрема аумка суАді Конституційного Суду України Шевчука С. В. стосовно Рішення Конституційного Суду України у справі за конституційним поданням 59 народних депутатів України щодо віАповіАності Конституції України (конституційності) статті $368^{2}$ Кримінального кодексу України, https://zakon.rada.gov.ua/laws/show/nh01d710-19\#Text.

${ }^{49}$ Franklin v. State, 257 So. 2 d 21 (Fla. 1971).
} 
чи «мерзенний та огиАний зАочин проти природи» вкмючає оральний секс або тільки анацьний. Рішеннями віА 24 мютого 1972 р. у справі Папахрісту проти міста Ажексонвіля ${ }^{50}$ та віА 2 травня 1983 р. у справі Колендер проти Аоусона ${ }^{51}$ Верховний СуА США скасував закони проти броАяжництва за неконституційну невизначеність, оскільки закон залишив на розсуА поліції обмеження такої Аіяльності, як «неробство», «манАри», або «блукання з місця на місце», i, оскільки мюАи не могли певно знати, якого роду повеАінка заборонена законом, то могли потенційно понести кримінацьну відповідальність за безвинну повсякаенну аіяльність. Рішенням віА 15 червня 1983 р. у справі Місто Акрон проти Акронського Центру репродуктивного здоров' ` $^{52}$ Верховний Суа США скасував положення місцевого закону про аборти, який вимагав, щоб

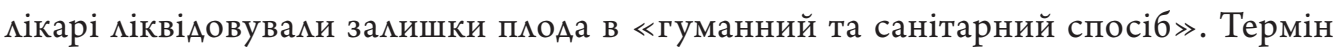
«гуманний» було визнано Судом неконституційно розпливчастим Аля визначення поведінки суб’єкта кримінальної віАповіАальності, аАже мікар не міг бути впевнений, $\epsilon$ його повеАінка законною чи ні.

Британська правова Аоктрина критерієм «звичайної розумної мюАини» визначає особу з мави присяжних або «пасажира з автобусу в Клепхемі» ${ }^{53}$ (тобто усереАнену за розумовими зАібностями, освітою та статком мюАину, яка, віАповіАно, має звичайний рівень інтелекту, знань та життєвого АосвіАу). ${ }^{54}$ Це є важливим критерієм правової визначеності, а саме зрозумілості та передбачуваності правових приписів Аля пересічного громадянина, а не тільки Аля професійних юристів (суААів, аАвокатів, науковців тощо).

Вищенаведені критерії $€$ відбиттям зв'язків та взаємозумовленості правової визначеності та інших загальних принципів права і водночас вимог верховенства права, зокрема законності (у цій площині «легітимні очікування» legitimate expectations $€$ «законними очікуваннями» rightful expectations) та розумності (у цьому аспекті «легітимні очікування» розглядаються як «розумні очікування» reasonable expectations). Ефективне забезпечення цих зв'язків, упровадження правової визначеності та ії елементів у нормотворчість і правозастосування, передусім у судову практику, а отже, реальне вкорінювання верховенства права та його вимог у націонахьну правову систему, $є$ преАметом професійної відповіАальності як вітчизняних правознавців, так і юристів-практиків.

(C) В. Смородинський, 2020

\footnotetext{
${ }^{50}$ Papachristou v. City of Jacksonville, 405 U. S. 156 (1972).

${ }^{51}$ Kolender v. Lawson, 461 U. S. 352 (1983).

${ }^{52}$ City of Akron v. Akron Center for Reputive Health, 462 U. S. 416 (1983).

${ }^{53}$ Петришин та ін. Загальна теорія права, 198.

${ }^{54}$ У доповіАі «Право і неправо з точки зору авіаційного техніка» на Всеукраїнському круглому столі «Фундаментальні проблеми юриспруденції II. Право і неправо» (18-19 вересня 2020 р., м. Харків, НЮУ ім. Ярослава Мудрого, НАПрНУ) автор запропнував як зрозумілий вітчизняний

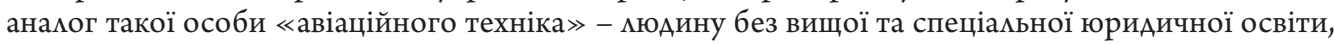
але - з огляду на скмадні професійні обов'язки, повязані з безпекою та життям великих груп ^юдей, - $з$ достатнім інтелектом, освіченістю та почуттям соціальної відповіАальності.
} 


\section{Bibliography}

Belianevych, Olena. "The Concept of Legitimate Expectations and Problems of its Application by the Ukrainian Courts." Pryvatne pravo i pidpryemnytstcvo 16 (2016): 41-45 (in Ukrainian).

Berzanyuk, Jan. "he Ratio of the Need to Ensure the Unity of Judicial Practice and Deviation from the Legal Positions of the Supreme Court (on the example of resolving public law disputes)." Sudebno-yuridicheskaya gazeta, August 26, 2020, https://sud.ua/ru/news/blog/177404-spivvidnoshennya- neobkhidnosti-zabezpechennya-yednosti-sudovoyi-praktiki-ta-vidstupu-vid-pravovikh-pozitsiy- verkhovnogo-sudu-na-prikladi-virishennya-publichno-pravovikh-sporiv?fbclid=IwAR2D9EastZc6_ic oWnIGyUwMUIzxKUw2X1w3RWPgdg7LEoQuV798suRpCHg(in Ukrainian).

Bingham, Tomas. "The Rule of Law." http://legalitas.com.ua/ua/ukr-t-bin\%D2\%91em-verxoven-stvoprava/ (in Ukrainian).

Bogachova, Lyudmila. "The Principle of Legal Certainty in European and National Law (Substantive Characteristics).” Teoriya i praktyka pravoznavstva 2 (2013). http://nbuv.gov.ua/UJRN/tipp_2013_2_74 (in Ukrainian).

Fuller, Lon L. The Morality of Law. Kyiv: Sfera, 1999 (in Ukrainian).

Hayek, Friedrich August von. The Road to Serfdom: text and documents, edited by Bruce Caldwell. Definitive ed. London: The University of Chicago Press, 2007.

Matveeva, Yuliya. "Legal Certainty and Judicial Lawmaking." Nauk. zapiski nats. un-tu "Kyevo-Mogylans'ka akademiya”. Vol. 103: Yurydychni nauky, 50-53. Kyiv, 2010 (in Ukrainian).

Petryshyn, Oleksandr, Dmytro Lukianov, Sergyi Maksymov, Viktor Smorodynskyi et al. General Theory of Law. Kharkiv: Pravo, 2020 (in Ukrainian).

Pohrebnyak, Stanislav. Fundamental Principles of Law (Substantive Characteristics). Kharkiv: Pravo, 2008 (in Ukrainian).

Rule of Law. Report no. 512/2009 (Venice Commission, Strasbourg, 4 April 2011 p.). https://www. venice.coe.int/webforms/documents/default.aspx?pdffile $=\mathrm{CDL}-\mathrm{AD}(2011) 003 \mathrm{rev}-\mathrm{ukr}$.

Rule of Law Checklist. Study no. 711/2013 (Venice Commission, Strasbourg, 18 March 2016). https:// www.venice.coe.int/webforms/documents/default.aspx?pdffile=CDL-AD(2016)007-e.

Rule of Law Checklist. Commentary. Glossary. Translated by Sergiy Holovaty. USAID, 2017 (in Ukrainian). Smorodynskyi, Viktor. “Judiciary in Ukraine (general theoretical problems).” PhD diss., Kharkiv, 2001 (in Ukrainian).

Summers, Robert S. “The Principles of the Rule of Law.” Notre Dame Law Review 74 (1999): 1691-712.

\section{Віктор Смородинський. Правова визначеність}

Анотація. Правова визначеність розглядається у статті не лише як один із загальних принципів права та одна з вимог верховенства права, а й загалом як засаднича властивість і умова значущості права та його інструментальної цінності. У цьому зв'язку аналізуються визначення верховенства права та переліки його складових, запропоновані захіАними філософами і теоретиками права та Венеційською комісією. Висвітлюються такі елементи принципу правової визначеності, як Аоступність законодавства та судової практики, передбачуваність правовових актів, принципи єАності судової практики, мегітимних очікувань, res judicata, європейська концепція автономного тлумачення та американська доктрина невизначеності закону. Шмяхом аналізу та 
синтезу теоретичних концепцій принципу правової визначеності, практики його тлумачення й застосування європейськими та національними судами, зв’язків між ним та іншими загальними принципами права (зокрема законності та розумності) доводиться визначна роль цього принципу в укоріненні верховенства права у національній правовій системі.

Ключові слова: правова визначеність; загальні принципи права; верховенство права; єАність судової практики; мегітимні очікування; автономне тлумачення; автономні поняття; законність; res judicata; доктрина невизначеності закону.

\section{Виктор Смородинский. Правовая определенность}

Аннотация. Правовая определенность рассматривается в статье не только как один из общих принципов права и одно из требований верховенства права, но и вообще как основополагающее свойство и условие значимости права и его инструментальной ценности. В этой связи анализируются определения верховенства права и перечни его составмяющих, преАложенные западными философами и теоретиками права и Венецианской комиссией. Освещаются такие элементы принципа правовой определенности, как доступность законодательства и судебной практики, предсказуемость правовых актов, принципы единства судебной практики, мегитимных ожиданий, res judicata, европейская концепция автономного толкования и американская Аоктрина неопределенности закона. Путем анализа и синтеза теоретических концепций принципа правовой определенности, практики его толкования и применения европейскими и национальными судами, связей межАу ним и другими общими принципами права (в частности, законности и разумности) доказывается определяющая роль этого принципа в укоренении верховенства права в национальной правовой системе.

Ключевые слова: правовая определенность; общие принципы права; верховенство права; единство судебной практики; мегитимные ожидания; автономное толкование; автономные понятия; законность; res judicata; Аоктрина неопределенности закона.

\section{Viktor Smorodynskyi. Legal Certainty}

Abstract. Legal certainty is considered in the paper not only as one of the general principles of law and one of the requirements of the Rule of Law, but also as a fundamental feature and condition of the significance of law and its instrumental value in general. In this regard, the definitions of the Rule of Law conception and the lists of its components proposed by Western philosophers and theorists of law and by the Venice Commission are analyzed. Elements of the principle of legal certainty such as legislation and case law accessibility, legal acts' predictability, principles of case law unity, legitimate expectations, res judicata, the European concept of autonomous interpretation and the American doctrine of uncertainty of law are covered. By analyzing and synthesizing theoretical concepts of the principle of legal certainty, the practice of its interpretation and application by European and national courts, the connections between it and other general principles of law (in particular - principles of legality and reasonableness), this principle plays a key role in the Rule of Law implementation in the national legal system.

Keywords: legal certainty; general principles of law; Rule of Law; case law unity; legitimate expectations; autonomous interpretation; autonomous concepts; legality; res judicata; doctrine of uncertainty of the law.

ОАержано/Received 30.09.2020 